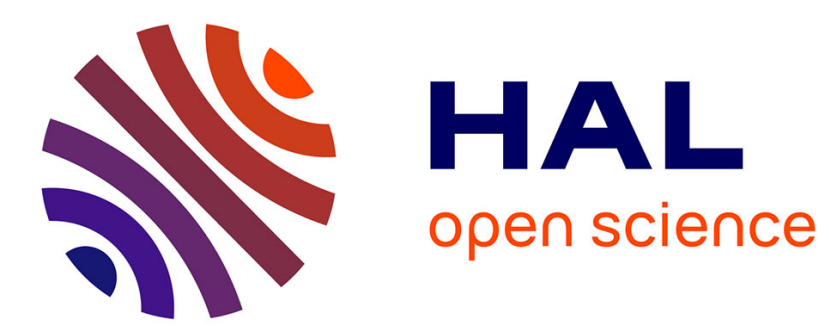

\title{
The taxonomic content of the genus Gavialis from the Siwalik Hills of India and Pakistan
}

\author{
Jérémy Martin
}

\section{To cite this version:}

Jérémy Martin. The taxonomic content of the genus Gavialis from the Siwalik Hills of India and Pakistan. Special papers in palaeontology, In press, 10.1002/spp2.1247 . hal-02123647

\section{HAL Id: hal-02123647 \\ https://hal.science/hal-02123647}

Submitted on 8 May 2019

HAL is a multi-disciplinary open access archive for the deposit and dissemination of scientific research documents, whether they are published or not. The documents may come from teaching and research institutions in France or abroad, or from public or private research centers.
L'archive ouverte pluridisciplinaire HAL, est destinée au dépôt et à la diffusion de documents scientifiques de niveau recherche, publiés ou non, émanant des établissements d'enseignement et de recherche français ou étrangers, des laboratoires publics ou privés. 


\title{
The taxonomic content of the genus Gavialis from the Siwalik Hills of India and Pakistan
}

\author{
by JEREMY E. MARTIN ${ }^{1}$
}

${ }^{1}$ Univ. Lyon, UMR 5276 CNRS, Laboratoire de Géologie de Lyon: Terre, Planètes, et Environnement, École Normale Supérieure de Lyon et Université Lyon 1, 69364 Lyon, France; email: jeremy.martin@ens-lyon.fr

\begin{abstract}
The fossil record of the genus Gavialis currently harbors nine species, many of which were erected from the mid XIX ${ }^{\text {th }}$ to early $\mathrm{XX}^{\text {th }}$ century, sometime on the basis of incomplete specimens. A survey of the Natural History Museum of London collections, where many specimens were collected in the course of geological surveys in Punjab and Sindh, part of the former Indian Empire, provides a basis to reevaluate the taxonomic content of the genus Gavialis. Four species, G. leptodus, G. pachyrhynchus, G. curvirostris and G. breviceps, are not referable to the genus
\end{abstract} Gavialis. The species G. hysudricus is considered a junior synonym of G. gangeticus. The genus Gavialis includes two species namely G. gangeticus and G. bengawanicus; two others, G. browni and G. lewisi require revisions. Several similarities are noted between the tomistomine Rhamphosuchus crassidens and G. leptodus, G. pachyrhynchus, G. curvirostris and G. breviceps. As a generality, the scarcity of information on sampling locations renders difficult a discussion on taxon provenance and age. However, a definitive revision of these taxa requires a revision of $R$. crassidens as well as an improved stratigraphic framework for all these taxa in a continuing effort to update the diversity of Gavialis and other longirostrine forms in the Mio-Plio-Pleistocene of India-Pakistan and SE Asia.

Key words: Gavialis, India, Pakistan, Siwalik Hills

THE LIVING gharial, Gavialis gangeticus, inhabits the fresh waters of India and Nepal. In the recent past (i.e. about a century ago) its distribution was wider and encompassed Bangladesh, Bhutan with Pakistan, where it is possibly extinct and also Myanmar, where it is now definitely extinct (Choudhury et al. 2007). Recent 
palaeontological studies have confirmed that about 2 million years ago, another species of Gavialis, G. bengawanicus Dubois 1908 was also present in SE Asia with fossil specimens recovered as far as Java (Delfino and De Vos 2010) and Thailand (Martin et al. 2012). Several species of Gavialis are known from older localities of various ages from the Siwalik Hills of India and Pakistan and the current hypothesis places the origin of Gavialis in this area, with subsequent dispersal through fluvial capture from the Siwaliks to Java during the Plio-Pleistocene (Claude et al. 2011; Martin et al. 2012). This hypothesis relies largely on the fossil record of Gavialis species, the great majority of which have been discovered in the Siwalik Hills of India and Pakistan. However, since the work of Lull (1944), the taxonomic content of the genus Gavialis has not been revised. The goal of this project is therefore to provide a preliminary revision of the material from India and Pakistan on the basis of specimens curated in NHMUK.

The most recent literature on the fossil record of Gavialis gives an inventory of nine species spanning the Miocene, Pliocene and Pleistocene, most of them from the Siwalik Hills of India and Pakistan (Lull, 1944). Species of Gavialis include G. gangeticus (Gmelin 1789), G. leptodus (Cautley 1868), G. pachyrhynchus Lydekker 1886, G. hysudricus Lydekker 1886, G. curvirostris Lydekker 1886, G. bengawanicus Dubois 1908, G. breviceps Pilgrim 1912, G. browni Mook 1932 and G. lewisi Lull 1944. However, the taxonomic status of many of these species has been questioned (Brochu, 1997; Delfino \& De Vos, 2010; Martin et al. 2012). Furthermore, the presence of Rhamphosuchus crassidens Cautley (1840) in the Siwalik Hills (Head, 2001) indicates that the fossil record of another longirostrine lineage, the Tomistominae, must be taken into account. Considering that some species of Gavialis have been erected on the basis of fragmentary specimens, the gavialoid/tomistomine distinction may not always be obvious. The aim of this work is therefore to clarify the taxonomic content of the genus Gavialis from Neogene deposits of India and Pakistan on the basis of the collections in NHMUK.

Abbreviations. IM, Indian Museum, Calcutta; NHMUK, Natural History Museum United Kingdom;

\section{HISTORICAL BACKGROUND}


Fossil Gavialis species curated in NHMUK and IM come from two distinct areas. The first specimens, part of the famous Siwalik fauna, were collected from Punjab region in nowadays northern India and Pakistan in the 1830s and the context of their discovery and collecting efforts have been largely covered in the work of Nair (2005). The second area has yielded older faunas and concerns the region of Sindh in nowadays Pakistan.

The large collection of fossils from the Siwalik Hills of India curated in the NHMUK finds its roots in the collaboration of two persons with different professional backgrounds: Captain Proby Cautley and Dr. Hugh Falconer. Cautley was an engineer supervising the building and restoration of irrigation canals in northern India since 1828 (see Brown, 1980 for biographic details), commissioned first as a superintendent on the Doab canals along the Jumna (Yamuna) River. Falconer was a naturalist and worked as a surgeon-botanist at Saharanpur Botanic Gardens from 1831 (see Murchison (1868) for biographic details). Cautley was able to dedicate manpower to explore, extract and carry numerous fossils discovered during canal work. Although not able to work out the identity of the fossils, Cautley built in a matter of two years the largest private collection of fossils from the Siwaliks, which was soon considered of great importance from the Asiatic Society of Bengal. Falconer played a pivotal role in identifying and recognizing the scientific importance of such a gathering, with many of the scientific works being compiled in the Palaeontological Memoirs (1868). Cautley, with the help of Falconer as well as two other persons known as Baker and Durand, gathered a massive collection in Saharanpur. From 1836, Cautley engaged in a process to donate the fossil collection to an institution, which eventually turned out to be accepted by the British Museum. By 1846, a total of 236 chests containing the fossil collection from the Siwaliks had been shipped to London (Brown, 1980).

Later collecting efforts were made in the Bugti Hills and Laki Hills of Sindh, in nowadays Pakistan with several type specimens curated in the IM Calcutta collections. The circumstances of their discoveries are poorly known and locality names and provenance data are limited. Lydekker (1886) is the first to describe those specimens and mentions Francis Fedden, a geologist of the Geological Survey of India, as a discoverer. Guy E. Pilgrim FRS was a geologist and palaeontologist working for the Geological Survey of India. He went on fieldwork in the Bugti Hills in 1907 and 1908. Pilgrim $(1908,1912)$ revised the work of Lydekker (1886) and erected a new species of Gavialis. 


\section{GEOGRAPHIC AND STRATIGRAPHIC CONTEXT}

Locality data of the NHMUK specimens are never specified on the labels.

Information on provenance is generally restricted to the type of formation from which a given specimen is derived (e.g. Siwalik Hills of India) either on the label or in the literature when curation numbers allow the specimens to be traced back to a given work (e.g. Lydekker, 1886; Pilgrim, 1912). Here, most of the finds assigned to Gavialis come from Punjab, which nowadays corresponds to the tract of foreland hills north of New Delhi and across the India-Pakistan border. A number of specimens also originate from the tract of mountain in Sindh, which correspond to today's Western Pakistan. In the middle of the XIXth century, the name "Punjab" was used for a vast area from the Himalayas near Nahun to the East, to the Salt Range in nowadays Pakistan to the West. The areas of interest have been mentioned in the attached map (Figure 1). All these areas are part of the Siwalik Hills, which consist of a large stack of detritic deposits resulting from the weathering of the Himalayas. Below, I provide details on provenance data as indicated on labels or on the associated XIXth century literature, beginning with the youngest strata.

\section{Siwalik Hills of India (early Pleistocene)}

The earliest account on the provenance of gavials from the Siwalik Hills is that of Cautley (1836). He specifies that the fossils have been recovered in great abundance between the Jumna and the Sutlej rivers. Apparently, Cautley did not take part in all the excavations but his role was to assemble the discoveries made by his personnel. As such, Cautley (1836) reports that many fossil discoveries come from the vicinity of the village of Deoni in the Náhan Raja's territory (corresponding to today's Nahun area), acknowledging: "the position of the stratum (...) was not satisfactorily determined". In another locality, the Ambwalla Pass, a large bone fragment was found in situ and allows Cautley (1836) to state that fossils are not only coming from sandstones but also from clays and clayey conglomerates.

Cautley (1840) indicates that the Siwalik Hills correspond to a tract of mountains between the Jumna and Ganges rivers and reports vertebrate fossils including "Ghariál" teeth and bones as well as "Crocodile" teeth in abundance. Cautley (1840) adds: "The greater part of the fossils, already procured, is from the 
deposit in the Kalowa Pass", which is one entry to the Deyra Valley. According to him, all these fossils were found in marls and are deep black in colour. Cautley (1840) makes reference to another area, West of the Jumna River, where similar fossiliferous marls containing, among other remains, those of crocodiles, crop out North of the city of Nahun (Nahan, Himachal Pradesh, India), close to the Markanda River. In this area, soft sandstones contain fossil bones with ferruginous concretions.

In Falconer's Palaeontological Memoir (1868, Plate II), the Siwalik Hills (spelled Sewalik Hills) are represented as a stretch of sediments south of the Himalaya, extending from the Hydaspe River in Pakistan to the Gandaki River in Nepal. The fossil fauna reported in the Palaeontological memoirs originates from the exploration of areas between the Sutlej and Ganges Rivers (page 10).

Although localities are never indicated on NHMUK labels, it is highly possible that the fossil Gavialis specimens with the label "Siwalik Hills" come from a stretch between the Jumna and Sutlej rivers near today's city of Nahun as well as the Ambwalla Pass. The canal work under the supervision of Cautley was indeed taking place in this area (Cautley, 1840).

This geographic zone, also known as the Chandigarh region, has yielded abundant mammalian and reptilian faunas and is considered to be part of the Upper Siwalik (Paitnak \& Nanda, 2010; Nanda, 2013; Nanda et al. 2016), where two biostratigraphic intervals are currently recognized: the oldest is the Saketi Formation (an equivalent of the Tatrot Formation according to Nanda (2002) and Verma (1988)), which is considered as upper Pliocene with the Elephas planifrons Interval-Zone dated between 3.6 and 2.6 Ma according to Nanda (2002). Nanda et al. (2016) recently reported Crocodylus aff. palustris and Rhamphosuchus crassidens from the Tatrot beds. The other biostratigraphic interval is the overlying member, known as the Pinjor Formation and is considered early Pleistocene with the Equus sivalensis Interval-Zone dated between 2.6 and $0.6 \mathrm{Ma}$ according to Nanda (2002). Nanda et al. (2016) report Gavialis cf. gangeticus from the Pinjor beds from several localities but not from pre-Pinjor beds. Worth noting is the report by Patnaik \& Schleich (1993) of G. cf. gangeticus south of Nahan in two localities interpreted to be early Pleistocene, known as Saketi and Moginand, on both sides of the Markanda River. Therefore, it seems likely that specimens of the genus Gavialis labeled as being from the Siwalik Hills of India in NHMUK and collected by Cautley and Falconer parties in the 
Chandigarh region are all from the youngest Pinjor Formation and should be considered early Pleistocene in age.

\section{Lower Siwaliks of Sindh (Middle Miocene)}

The Laki Hills are exposed close to the city of Sehwan, Sindh province, Pakistan. Lydekker (1886) and then Pilgrim (1908) reported discoveries of Gavialis from the Lower Siwaliks of Sindh. Lydekker (1886) refers to Mr. F. Fedden as a collector of fossils from this area. Pilgrim (1908) reports vertebrates from the Lower Siwaliks of Sindh including: Crocodilus palaeindicus Falconer 1859, Garialis pachyrhynchus Lydekker 1886, Garialis curvirostris. He discusses the age of this fauna to be Sarmatian or Tortonian (Miocene), i.e. younger that the Upper Nári series (see below). Lull (1944) considers the Laki Hills of Sindh to be part of the Chinji Formation, Lower Siwalik, Upper Miocene in age. However, recent biostratigraphic calibrations reveal that the Chinji Formation spans between about 14 and $11 \mathrm{Ma}$, corresponding to the middle Miocene (Flynn et al. 2016).

\section{Kumbi, Bugti Hills (Late Oligocene)}

Pilgrim (1908) reports crocodylians from the Upper Nári series, including Crocodilus bugtiensis n. sp., Crocodilus naricus n. sp., Garialis curvirostris Lyd. n. var.. Pilgrim (1908) argues that this series is Aquitanian (Miocene). More detailed stratigraphic works have been made in the northern area of the Sulaiman geological province, notably in the Pakistani province of Balochistan. Confirming previous suggestions made by Blanford (1883) and Friedman et al. (1992), Welcomme et al. (2001) did study sedimentary sections in the Bugti Hills of Balochistan and identified the "Nari Formation", which they attribute to the Oligocene.

\section{GAVIALIS FROM THE NEOGENE OF INDIA AND PAKISTAN}

In this section, a comprehensive account of the fossil specimens catalogued as Gavialis in the NHMUK collections is provided and their taxonomic validity is discussed. Several specimens have been described and figured in the literature but a number of specimens in NHMUK bear old labels and are thought to be part of the Cautley collection. The original specific allocations are presented chronologically, 
with the work of Cautley (1836) representing the oldest mention of the genus from the Siwalik Hills.

The NHMUK palaeontological collection and associated XIXth and early XXth century literature inconsistently refer to the genus Gavialis, Garialis or Gharialis. Cautley (1836) provides some explanation for such a discrepancy: "The French mode of writing this word, Gaviál, appears to have originated in a misreading of the manuscript of some naturalist; the $r$ and $v$ being nearly similar in form. As Ghariál is the correct native name, there seems no reason for perpetuating the misnomer." (Asiatic researches 1836, footnote page 32). This difference has perpetuated in the vernacular use of the extant name with gharial in English versus gavial in French but for some reason the Latinised genus name Gavialis has been retained since its first use by Oppel (1811 p.19).

\section{Gavialis gangeticus (Gmelin, 1789)}

Material. Seven specimens can be confidently identified as belonging to Gavialis gangeticus and five of them representing the best-preserved specimens are figured (Fig. 2). NHMUK R.774 (not figured), a skull table missing the postorbitals; NHMUK R.785, a skull table with almost complete orbits and the posterior portion of the ventral side of the skull; NHMUK R.786, a skull table with almost complete orbits, broken off squamosals and the posterior portion of the ventral side of the skull; NHMUK R.791 (not figured), A skull table with partly eroded orbits; NHMUK R.36726, a skull table with almost complete orbits, part of the rostrum and posterior mandibular rami in occlusion; NHMUK R. 36727, posterior part of the skull with occluding mandibles; NHMUK R.39809, a large skull table with almost complete orbits and the posterior portion of the ventral side of the skull. Rostra are consistently broken off and missing. Several other specimens are too fragmentary and can only be assigned to Gavialis sp. (Fig. 3).

Provenance. All these specimens bear a label referring to the Siwalik Hills of India. They may come from different outcrops between the Sutlej and Ganges rivers in the Chandigarh region.

Age. Pinjor Beds, early Pleistocene, Upper Siwalik faunas of India. 
Discussion. Most of the specimens with a label indicating the Siwalik Hills can be assigned to Gavialis sp. and show the following combination of diagnostic characters of the genus: prominent basioccipital tubera, large supratemporal fenestrae, frontal reaching the supratemporal fenestrae, wide interorbital width, upturned orbits (see emended diagnosis in Martin et al. 2012). This review of the NHMUK collections led to the recognition of six specimens confidently assignable to Gavialis gangeticus (NHMUK R.774, R.785, R.786, R.791, R. 36726, R.36727 and R.39809) (Fig. 2). In addition to the diagnostic characters of Gavialis sp. (see above), all these specimens display at least one of the diagnostic characters of the species G. gangeticus (see Delfino \& De Vos, 2010; Martin et al. 2012) such as the laterally sloping skull table as observed in posterior view or the $\mathrm{V}$-shaped palatine-maxillary suture. A seventh specimen, NHMUK R.36727, is very similar to some of the above-mentioned specimens but the mandible in occlusion precludes a definitive observation of the palatine-maxillary suture. Those specimens differ from G. bengawanicus in possessing a prominent projection of the supraoccipital from the occipital surface of the skull.

Two specimens represented by rostra present a depression posterior to the external nares and in the specimen where the ghara is expressed (NHMUK R39811a), a pair of spines distinctly protrude from the anterolateral edge of the narial margin (Fig. 3). This character is present, but less evident, in NHMUK R.48461. In another rostrum (NHMUK R.39811), the ghara is not developed (see Martin \& Bellair, 1971 for variability).

Several specimens are remarkable in possessing slightly larger sizes than extant specimens. There are 16 skulls from the NHMUK collections belonging to the extant $G$. gangeticus, including juveniles and adult specimens, with the longest skull (from the anterior tip of premaxilla to the posterior end of skull table) attaining 74.6 $\mathrm{cm}$ and possessing a width across the quadratojugals of $31 \mathrm{~cm}$ (NHMUK 1847.12.20.4). Out of the seven fossil specimens assignable to Gavialis gangeticus, three fossil individuals particularly stand out from the modern dataset being slightly larger than modern counterparts. The longest extant G. gangeticus skull reported in the literature is $77.3 \mathrm{~cm}$ (Whitaker, 2008). Here, the largest fossil specimen of $G$. gangeticus (NHMUK R.39809) has a width across the quadratojugals of $39.5 \mathrm{~cm}$ and an inferred skull length of $85.5 \mathrm{~cm}$. The two other large fossil skulls of G. gangeticus 
belong to NHMUK R.791 and NHMUK R.39809, which both possess a width across the quadratojugals of $36 \mathrm{~cm}$.

The oldest Gavialis gangeticus fossils have been considered to be Pliocene in age (Lydekker, 1886). Here, a definitive record of G. gangeticus older than the early Pleistocene cannot be confirmed at least in the Chandigarh region. Gavialis lewisi Lull 1944, which taxonomic status requires a revision (see below) was collected in the Dhok Pathan Formation of Pakistan, which is considered Pliocene in age. Four partial skulls (NHMUK R.222, R.772, R.1220 and R.40695) from the late Miocene of Perim Island, Gulf of Cambay, India, present diagnostic characters of the genus Gavialis but are too fragmentary to warrant a specific assignment.

Conclusions. Several specimens curated in NHMUK are too fragmentary to allow a specific allocation. However, they preserve diagnostic features of the genus Gavialis. For these reasons, these specimens are referred to Gavialis sp.

Nevertheless, seven relatively complete specimens present all the features diagnostic of the species Gavialis gangeticus. G. gangeticus from the Siwalik Hills of India is here considered early Pleistocene in age.

Gavialis hysudricus Lydekker, 1886

Material. Lydekker (1886) erected Gavialis hysudricus on one specimen previously assigned to Gavialis leptodus in Cautley (1868, Plate XXIX, fig. 3). The holotype of G. hysudricus is registered under NHMUK R.39805 and consists of a nearly complete rostrum lacking the premaxillae, preserving part of the suborbital fenestra and ectopterygoid as well as a partial lower jaw attached to it (Fig. 4A, B). This specimen is figured in dorsal, ventral and lateral views, without the mandible attached to the block as in Lydekker (1886, plate XXXII, figs 1, 1a, 1b, 1c). Three other specimens have been referred to G. hysudricus: NHMUK R.325 (Fig. 3G-H), which consists of the posterior portion of a mandibular symphysis with participation of the splenial, briefly mentioned in Lydekker (1886); NHMUK R.39808 (Fig. 5E-H), posterior portion of a skull figured in Lydekker (1886, plate XXXI, fig. 3) and NHMUK R.325a (Fig. 5A-D), a posterior portion of a skull from the Siwalik Hills of India labeled as G. hysudricus. 
Provenance. All these specimens are from the Siwalik Hills, as noted by Lydekker (1886, p. 222). According to Lull (1944), the holotype of G. hysudricus comes from the neighborhood of the Satlej (today's Sutlej) Valley. According to Piras \& Kotsakis (2005), G. hysudricus comes from the Dhok Pathan Formation but the authors seem to be referring only to the specimen NHMUK R. 39808 (see Piras \& Kotsakis, 2005, fig. 5), which is not conspecific with NHMUK R. 39805, i.e. the holotype of $G$. hysudricus (see discussion below). I have not been able to identify any locality data for NHMUK R.39808 and NHMUK R.325a.

Age. Pinjor Beds, early Pleistocene, Upper Siwalik faunas of India.

Discussion. The holotype of G. hysudricus (NHMUK R.39805; Fig. 4) shares several diagnostic characters with G. gangeticus: the extent of the ectopterygoid along the border of the suborbital fenestra; the extent of the splenial in the symphysis (comprising 10 alveoli); the spaced out mandibular and maxillary alveoli with adjacent pits; the narrow width of the dentary and maxilla; and the forward triangular projection of the palatine anterior to the anterior level of the suborbital fenestra and encompassing 4 alveoli. The frontal process in the interorbital region is projecting far anteriorly, as in modern Gavialis. As in the extant species, the maxillary region close to the tooth row and just anterior to the suborbital fenestra is beveled. There is therefore no evidence warranting the specific validity of Gavialis hysudricus. The mandible NHMUK R.325 assigned by Lydekker (1886) to the same genus is of similar size as that in the holotype. There are at least 9 alveoli included in the splenial symphysis but alveoli are not always well preserved and the tip of the splenial is damaged. There is no diagnostic character for this specimen and NHMUK R.325 might just be referred as a large Gavialis sp. individual.

The posterior part of the skull NHMUK R.39808 is markedly different from a typical modern G. gangeticus skull and agrees in many points with the slightly smaller skull NHMUK R.325a (Fig. 5). The skull table is planar in posterior view and not sloping as in G. gangeticus, the interorbital space is particularly narrow; the postorbital bar is massive and circular for its entire length in cross section. In $G$. gangeticus, the postorbital bar is mesiodistally expanded and laminar in cross section. The supratemporal fenestrae of NHMUK R.39808 and NHMUK R.325a are slightly smaller than the orbits, which is the opposite in G. gangeticus. The dorsal surface of 
the quadratojugal in NHMUK R. 39808 is profusely ornamentated with pits. This area is not preserved in NHMUK R.325a. In G. gangeticus, the dorsal surface of the quadratojugal is completely smooth.

There is no evidence to maintain the status of $G$. hysudricus because its holotype cannot be distinguished from G. gangeticus. Linking the holotype of $G$. hysudricus with the skulls NHMUK R.325a and NHMUK R.39808 is problematic because the only overlapping part consists of the anterior tip of the frontal, which appears heavily damaged in NHMUK R.39808 and NHMUK R.325a. Although $G$. hysudricus can be considered a junior synonym of G. gangeticus, NHMUK R.325a and NHMUK R.39808 are clearly distinct from G. gangeticus and seem to represent a different, yet unnamed taxon. Although their generic attribution cannot be confirmed due to their fragmentary nature, it cannot be excluded that they also represent a different species of Gavialis. Only, the study of more complete specimens with clearly established provenance and age should provide a basis to evaluate their taxonomy.

Conclusions. Two skull tables (NHMUK R.39808 and NHMUK R.325a) cannot be assigned to Gavialis gangeticus and I agree with Lydekker (1886) on this point. However, both NHMUK R.39808 and NHMUK R.325a cannot be allied with the holotype of $G$. hysudricus due to the markedly different proportions of their interorbital space. The holotype of $G$. hysudricus resembles in all matters $G$. gangeticus and for this reason $G$. hysudricus should be considered a junior synonym of G. gangeticus. The mandible NHMUK R.325 is assigned to Gavialis sp.

Gavialis leptodus (Cautley, 1868)

Material. The species was erected in Falconer \& Cautley (1868) as Crocodilus leptodus. Although originally not described, two specimens (NHMUK R.39806; Fig. 6 and NHMUK R.39805; Fig. 4) were figured (Falconer and Cautley, 1868, plate XXIX figs. 3, 4) and referred to this species. The specimen label confirms this for specimen NHMUK R.39806: "Fig[ure]d in falconer's Pal. Mem. Vol. I Pl. 29, fig. 4". Lydekker (1886) designated NHMUK R.39806 (Fig. 6) as the type specimen of Gharialis leptodus, referred two other specimens (IM E 11 and IM E 12) to this species and moved out R.39805 of Gharialis leptodus to define it as the holotype of 
Gharialis hysudricus (see G. hysudricus section above). The type of G. leptodus, which should be considered as the lectotype, consists of a mandibular ramus (NHMUK R.39806; Fig. 6D-H; see also Lydekker, 1886, plate XXXII, fig. 2, 2a). In the same plate, Lydekker (1886) figures the two other specimens (IM E 11 in his fig. 3, 3a, 3b) and IM E 12 in his fig. 4). Finally, Lydekker (1886) mentions another specimen as Gavialis leptodus he refers to a mandible from the NHM (NHMUK R.39807; Fig. 6. A-C).

Provenance. Lydekker (1886) indicates that the lectotype NHMUK R.39806 comes from the typical Siwalik Hills. This information may point to outcrops of the Chandigarh area in northern India. As indicated by Lydekker (1886), another specimen (IM E 11), discovered in 1875 by Mr. Theobald and referred to G. leptodus, has a vague provenance, from the Siwaliks of the eastern Punjab. This is also consistent with the Chandigarh area.

Age. Uncertain; from the Tatrot Formation (late Pliocene) or Pinjor Formation (early Pleistocene).

Discussion. IM E.11 and NHMUK R.39807 are similar to the lectotype (NHMUK R.39806) in every respect but IM E 12 has not been located and according to Lydekker (1886)'s figure, it is not certain that it belongs to the same species (see below). Whether NHMUK R.39807 is a fragmentary mandible or maxilla is uncertain. The ventral surface of NHMUK R.39807 exhibits a deep V-shaped suture that could either correspond to the anterior tip of the nasal or to the splenial. The left tooth row, which is the longest to be preserved, shows 13 alveoli. Its dorsal surface is deeply depressed along the midline suture, as on the dorsal surface of the rostrum of the holotype of Ramphosuchus crassidens. The closely spaced alveoli and the relatively wide space between tooth rows recall specimens mentioned below for $G$. breviceps as well as features observed on the holotype of $R$. crassidens. A full redescription of $R$. crassidens may help compare and definitely evaluate whether $G$. leptodus is conspecific. Nevertheless, closely spaced alveoli, laterally protruding alveoli and small alveoli compared to the width of the rostrum are not features of the genus Gavialis and either a new genus name is needed for G. leptodus or its assignment to Rhamphosuchus needs to be assessed. 
In IM E 12, occlusal pits clearly appear between alveoli and a rim demarcates the alveolar row from the rest of the palatal surface. Actually, the morphology of IM E 12 is reminiscent of the posterior maxillary region in Gavialis sp.

Conclusion. The holotype of G. leptodus cannot be assigned to the genus Gavialis. A referral to Rhamphosuchus requires further, more detailed comparisons and will have to await a revision of $R$. crassidens. Specimen IM E 12 is referred to Gavialis sp.

Gavialis pachyrhynchus Lydekker, 1886

Material. Lydekker (1886) erected this species on the basis of the anterior portion of a large rostrum comprising the complete premaxillae and the anteriormost region of the maxillae (Lydekker, 1886, plate XXXIII, 1, 1a, IM E 30 (holotype) and its cast NHMUK R.602; Fig. 7). Lydekker (1886) also assigns a more fragmentary rostrum (Lydekker, 1886, plate XXXIII, 2, 2a, IM E 29) to the same species and notes that it was previously noticed by Falconer (1859) as Leptorhynchus, with the label 14 in the catalogue.

Provenance. According to Lydekker (1886), IM E 30 was collected by Mr. F. Fedden in the lower Siwaliks of the Laki Hills, Sindh, Pakistan; IM E 29 comes from the lower Siwaliks of Sehwan in Sindh according to Falconer (1859). G. pachyrhynchus comes from the Middle-Late Miocene of Chinji according to Piras \& Kotsakis (2005), but the authors do not provide references for that.

Age. middle Miocene.

Discussion. The size of IM E 30 is strikingly huge and immediately invites for a comparison with the holotype of Rhamphosuchus crassidens, which has a comparable size. Lydekker (1886) assigned IM E 30 to the genus Gavialis due to the outline of the narial opening, which has a thick and elevated contour and gives to the outline of the premaxilla a marked lateral expansion relative to the maxilla, as in the ghara of modern Gavialis gangeticus. In the holotype of $R$. crassidens, although the external nares are of comparable size, their contour is not similar to IM E 30 and the premaxillary lateral edge is in line with the maxillary rostrum. Moreover, in the 
holotype of $R$. crassidens, there is a pair of fossae in the anterior region of the narial opening, a feature previously noted by Martin \& Bellairs (1977). These fossae are not present in IM E 30 and instead, at this level, the median premaxillary suture hosts a large trough that spreads anteriorly to the tip of the premaxillae. It is delimited on its lateral edge by an anteriorly projecting lamina, which is only preserved in the right premaxilla. In modern Gavialis, the premaxilla in front of the narial fossa sometime bears a depression, which is often accompanied, in mature males, by a soft tissue narial excressence (Martin \& Bellairs, 1977). Whether this feature is variable in $R$. crassidens or in any gavialoids or longirostrine tomistomines is unknown.

Although I only had access to a cast, the drawing of the ventral view of specimen IM E 30 by Lydekker (1886) may not be accurate. Lydekker (1886) describes and represents three premaxillary alveoli in this specimen, but he also states that an accessory alveolus might be present between the first and second alveoli on the posterior side of the described notch, which is confirmed here. Inspection of the cast NHMUK R.602 of IM E 30 reveals that the premaxillary count might correspond to five alveoli on the right and four alveoli on the left row, but the last one is not visible in the cast. The arrangement of alveoli in IM E 30 is not comparable to that seen in Gavialis gangeticus in which alveolus 3 is separated from alveolus 4 by a large diastema. This is not the case in IM E 30 where alveolus 3 is contiguous with a slightly larger alveolus 4 . Another diastema separates alveolus 4 from alveolus 5 in $G$. gangeticus but in IM E 30, these alveoli are contiguous. As a result, the premaxillae in G. gangeticus are elongated but in IM E 30 are short, with the latter being identical in this regard to the holotype of Rhamphosuchus crassidens. The premaxillary count and relative dimensions of IM E 30 are very similar to those in the holotype of $R$. crassidens (R.39802).

Conclusion. G. pachyrhynchus is not comparable to the species of Gavialis, especially G. gangeticus for which the premaxilla is the best known. Major differences in premaxillary alveolar morphology invite to remove G. pachyrhynchus from the genus Gavialis. Several similarities including its gigantic size and alveolar arrangements, including the possession of 5 premaxillary alveoli, are shared with $R$. crassidens. Nevertheless, I did not examine the IM E 30 original specimen but a cast instead. No cast was available for IM E 29 and this specimen should be considered in the future. 
Differences in the shape of the narial opening with $R$. crassidens confirm that this taxon requires a revision (Head, 2001).

Gavialis curvirostris Lydekker, 1886

Material. The holotype (IM E 26) is broken in two pieces, which comprise the orbital region and the anterior tip of the rostrum (Lydekker, 1886, plate XXXI, figs. 1 and 2). Two other specimens were not figured by Lydekker (1886) and consist of the posterior portion of a skull (IM E 187) and of the posterior region of a maxillary rostrum (IM E 23). Pilgrim (1912) defined type specimens for the variety gajensis of the species Gavialis curvirostris. This includes a rostrum preserved to the anterior level of the suborbital fenestra and orbits (IM E 222), the posterior portion of a skull (IM E 228) (Pilgrim, 1912, plate XXVIII, figs. 1 and 2) and a mandibular symphysis (IM E 223) (Pilgrim, 1912, plate XXIX, fig. 1).

Provenance and age. The three specimens (holotype IM E 26), belonging to a single individual, mentioned by Lydekker (1886) are from the lower Siwaliks of the Laki Hills, Sindh, Pakistan. IM E 187 and IM E 23, also mentioned by Lydekker (1886) are also from Sindh. Gavialis curvirostris is from Chinji according to Piras \& Kotsakis (2005) but they do not provide references for that and whether this refers to the Chinji Formation or to a locality named "Chinji" remains unclear. Together with $G$. pachyrhynchus (see G. pachyrhynchus section above), Pilgrim (1908) reports $G$. curvirostris from the Upper Nári freshwater series of Balochistan, Pakistan and according to this information both taxa should be Oligocene in age following Welcomme et al. (2001). Pilgrim (1912) reports specimens of the gajensis variety from the Gaj of Kumbi, Bugti Hills. The Kumbi section described by Welcomme et al. (2001) includes fossiliferous levels of both Oligocene and Miocene age.

Discussion. I have not been able to observe the specimens first-hand. Not all specimens from the holotype (IM E 26) are presented in ventral view in the original description of Lydekker (1886). Two characters do not match the diagnosis of the genus Gavialis: the rims of the orbits are not overturned in IM E 26 and IM E 222 and the supratemporal fenestrae appear slightly smaller than the orbits in IM E 223. According to the plate of Pilgrim (1912), the maxillary count of IM E 222 is 14 
anterior to the level of the suborbital fenestrae, which is shorter than the count observed in G. gangeticus at this level (about 20). The premaxilla of G. curvirostris is overall similar to that of G. pachyrhynchus and Rhamphosuchus crassidens in the outline of the external nares and possibly also in premaxillary alveolar dimensions, positions and count (5) (compare IM E 26 in Lydekker, 1886, plate XXXI, fig. 2a with G. pachyrhynchus in Fig. 7). Nevertheless, the premaxilla is in line with the maxilla in $R$. crassidens but the premaxilla is slightly inflated laterally when compared to the maxilla in G. curvirostris. Whether this could be due to individual variation, sexual or ontogenetic differences needs to be assessed with more complete specimens from these localities and a full description of the remains attributed to $R$. crassidens from the Potwar Plateau (Head, 2001). Considering G. curvirostris is a subadult or a sexual variant of $R$. crassidens or G. pachyrhynchus will have some taxonomic consequences. More recently, a possible new species of Gavialis was reported from the early Miocene of Pakistan and could be close to G. curvirostris (Piras \& Kotsakis, 2005). This specimen is too fragmentary to allow a proper solving of the problems raised above. Pilgrim (1912) highlighted similarities between $G$. curvirostris and Tomistoma. I agree, given the small number of maxillary alveoli and the morphology of the orbits in G. curvirostris, which recalls the morphology of Tomistoma. Possible tomistomine affinities will have to be addressed with observations of the original specimens of G. curvirostris.

Conclusions. G. curvirostris is clearly not referable to the genus Gavialis and is possibly a member of the Tomistominae. The holotype (IM E 26), although broken according to Lydekker (1886), is preserved from the orbits to the premaxillae and should be compared with other putative large tomistomines such as G. pachyrhynchus or $R$. crassidens. It appears likely that all these three taxa might be conspecific, and if that is the case, $R$. crassidens should have priority. Whether the species name should be retained will have to wait for a review of the original specimens assigned to $G$. curvirostris, together with other taxa such as R. crassidens or G. pachyrhynchus.

Gavialis breviceps Pilgrim, 1912

Material. This species was erected by Pilgrim (1912) on the basis of specimens previously referred to G. curvirostris Lydekker 1886 by Pilgrim (1908). Pilgrim 
(1912) did not designate a particular holotype but included an indeterminate number of specimens. Of the specimens mentioned by Pilgrim (1912), the material defining G. breviceps consists of a mandible (Pilgrim, 1912, plate XXIX fig. 2, IM E 224) and several rostra (a large one is figured in Pilgrim, 1912, plate XXIX fig. 3 and another one in plate XXX fig. 1, 1a, both noted IM E 226). The other rostra are not figured in Pilgrim (1908 or 1912).

Provenance and age. As for G. curvirostris, Pilgrim (1912) makes references to Kumbi, Bugti Hills, Pakistan. The age is uncertain because fossiliferous levels occur both in the Oligocene and Miocene in this area according to Welcomme et al. (2001).

Discussion. The mandible IM E 224 is shown in occlusal view in Pilgrim (1912) and I did not examine it first hand. Pilgrim (1912) describes that 15 alveoli are situated in the mandibular symphysis of G. breviceps. The splenial involvement in the symphysis cannot be established, as the area would certainly require some preparation; whether it is short as in Tomistoma or long as in Gavialis remains unknown. I note that in the mandible of Rhamphosuchus crassidens (NHMUK R39803), the splenial is involved in the symphysis for 7 alveoli. In Gavialis gangeticus, the mandibular symphysis includes 23-24 alveoli and there are 11 alveoli involved in the splenial symphysis. In Tomistoma schlegelii, the mandibular symphysis includes 15 alveoli and there are 5 to 6 alveoli involved in the splenial symphysis. The closely spaced dentary alveoli of IM E 221 and the relative width of the dentary rami are different from the condition in $G$. gangeticus. However, these characters recall the condition seen in $R$. crassidens (NHMUK R39803) and the mandibular symphysis with 15 alveoli, as described by Pilgrim (1912) recalls T. schlegelii. Direct observations of IM specimens are warranted to clarify the morphology of the mandible of G. breviceps and evaluate its taxonomic referral to $R$. crassidens or to a new tomistomine.

The rostrum (IM E 226) figured by Pilgrim (1912) recalls $R$. crassidens in the morphology of the premaxillary alveoli. The anteriormost alveoli are missing and the second alveolus is not visible on the picture. The third and fourth alveoli are large and closely spaced and the fifth is slightly smaller. In dorsal view, the outline of the premaxilla is similar to G. pachyrhynchus (IM E 30), which was discussed above as a possible example of $R$. crassidens. The narial opening in IM E 226 is large and 
comparable to that of the holotype of $R$. crassidens and to G. pachyrhynchus (IM E 30).

Conclusion. At least the rostrum IM E 226 of G. breviceps is referable to Ramphosuchus crassidens. The mandible, also of very large size, could be referable to a large tomistomine, possibly $R$. crassidens or possibly a new genus. A comprehensive revision of $G$. breviceps should involve comparisons with $G$. pachyrhynchus and G. curvirostris. Direct observations on specimens from the Indian Museum are needed to validate these preliminary insights. What is certain, however, is that G. breviceps cannot be assigned to the genus Gavialis and might either be assigned to $R$. crassidens or to a new tomistomine.

\section{CONCLUSIONS AND PERSPECTIVES}

The genus Gavialis is represented by numerous specimens from the Pleistocene of the Siwalik Hills. G. hysudricus can be considered a junior synonym of G. gangeticus. A number of species previously assigned to the genus Gavialis such as G. leptodus, G. curvirostris, G. pachyrhynchus and G. breviceps are in fact suspected to belong to the Tomistominae. Their large sizes (except for G. leptodus) and morphological similarities with Rhamphosuchus crassidens invite to assess possible affinities between them. $R$. crassidens is awaiting a re-description based on new and more complete specimens from the Miocene of the Potwar Plateau in Pakistan (Head, 2001 ). Because $R$. crassidens was erected in 1840 , in case of synonymy it has priority over the above-mentioned problematic taxa. First, the stratigraphic distribution of $R$. crassidens should be assessed: according to provenance data from the Chandigarh area, $R$. crassidens should be Pliocene - Pleistocene in age, but Head (2001) reports the taxon from Miocene deposits of the Potwar Plateau. Here, the recognition of gigantic tomistomines through different Oligocene and Miocene localities of the Salt Range in Pakistan may either indicate that the genus Rhamphosuchus spanned a long record from the Oligocene to the Plio - Pleistocene, or that several gigantic longirostrine genera did exist at different times. A clear biostratigraphic record is currently lacking to understand whether tomistomines and gavialoids overlapped in time and space (possibly during the Pliocene) in the same environments or if 
gavialoids more recently colonized freshwater drainages of the Siwalik area, replacing older tomistomine faunas.

The fossil record of the genus Gavialis is strongly implanted in Pakistan, Asia and SE Asia as early as the early Pleistocene (see also Claude et al. 2011; Martin et al. 2012). Nevertheless, earlier records will have to be investigated. As such, two other species were not examined and will require a revision. The lower Pliocene Gavialis browni Mook, 1932, which consists of a nearly complete skull missing the anterior region of the rostrum was discovered one-mile south of Nathot, in nowadays Pakistan. Mook (1932)'s drawings do not allow the recognition of major differences with $G$. gangeticus, although the author argues that G. browni is more robust. The middle Pliocene Gavialis lewisi Lull, 1944 is represented by the posterior portion of a skull from Dhok Pathan, Pakistan. Lull (1944) recognized a close resemblance between his species and G. hysudricus. He did not compare G. lewisi with G. gangeticus but provided two differences with G. hysudricus including the relative width of the interorbital and parietal bars and the outline of the supratemporal fenestrae. However, our present understanding of G. hysudricus (see above) does not allow such comparison to be undertaken given that the only comparable material is NHMUK R. 39805. Whether G. lewisi represents a distinct species of Gavialis is not settled. Norell and Storrs (1989) argued that G. lewisi is distinct from G. gangeticus but Brochu (1997) notes that G. lewisi is probably a junior synonym of G. gangeticus and Delfino and De Vos (2010) could not detect differences in character codings between the two species. More recently, morphological similarities between G. lewisi and G. bengawanicus have been underlined (Martin et al. 2012). A detailed reexamination of G. lewisi and a comparison with other members of the genus Gavialis is needed. Gavialis sp. is known from Perim Island and, being of Late Miocene age, this locality may host the oldest representatives of the genus. For now, I can confidently recognize two species of Gavialis: G. gangeticus and G. bengawanicus. G. hysudricus is a junior synonym of G. gangeticus and G. browni requires a revision.

Acknowledgments. This research received support from the SYNTHESYS Project http://www.synthesys.info/ which is financed by the European Community Research Infrastructure Action under the FP7 Integrating Activities Programme (GB-TAF4750). I warmly thank Lorna Steel who provided all the necessary support during my visit at NHMUK. The last version of this work benefited from the detailed and 
constructive comments of two anonymous reviewers as well as from the editor P. Mannion and technical editor S. Thomas.

\section{REFERENCES}

BLANFORD, W. T. 1883. Geological notes on the hills in the neighbourhood of the Sind and Punjab frontier between Quetta and Dera Ghazi Khan. Memoirs of the Geological Survey of India, 22, 105-240.

BROCHU, C. A. 1997. Morphology, fossils, divergence timing, and the phylogenetic relationships of Gavialis. Systematic Biology, 46, 479-522.

BROWN, J. 1980. A Memoir of Colonel Sir Proby Cautley, F.R.S., 1802-1871, Engineer and Palaeontologist. Notes and Records of the Royal Society of London, 34, $185-225$.

CAUTLEY, P.T. 1836. Note on the fossil crocodile, of the Sivalik Hills. Asiatic Researches, 19, 25-38

CAUTLEY, P.T. 1840. On the structure of the Seválik Hills, and the organic remains found in them. Transactions of the Geological Society of London, second series, $\mathbf{5}$, $267-278$.

CAUTLEY, P. T. and FALCONER, H. 1840. XXXIV.-Notice on the remains of a fossil monkey from the tertiary strata of the Sewalik Hills in the north of Hindoostan. Transactions of the Geological Society of London, 2, 499-504.

CHOUDHURY, B. C., SINGH, L. A. K., RAO, R.J., BASU, D., SHARMA, R. K., HUSSAIN, S. A., ANDREWS, H. V., WHITAKER, N., WHITAKER, R., LENIN, J., MASKEY, T., CADI, A., RASHID, S. M. A., CHOUDHURY, A. A., DAHAL, B., WIN KO KO, U., THORBJARNARSON, J. and ROSS, J. P. 2007. Gavialis gangeticus. The IUCN Red List of Threatened Species, e.T8966A12939997.

CLAUDE, J., NAKSRI, W., BOONCHAI, N., BUFFETAUT, E., 
DUANGKRAYOM, J., LAOJUMPON, C., JINTASAKUL, P., LAUPRASERT, K.,

MARTIN, J., SUTEETHORN, V., TONG, H., 2011. Neogene reptiles of northeastern

Thailand and their paleogeographical significance. Annales de Paléontologie, 97, $113-131$.

DELFINO, M. and DE VOS, J. 2010. A revision of the Dubois crocodylians, Gavialis bengawanicus and Crocodylus ossifragus, from the Pleistocene Homo erectus beds of Java. Journal of Vertebrate Paleontology, 30, 427-441.

DUBOIS, E. 1908. Das Geologische alter der Kendeng-oder Trinilfauna. Tijdschrift van het Koninklijk Nederlandsch Aardrijskunding Genootschap, series 2, 25, 12351270.

FALCONER, H. 1859. Descriptive catalogue of the fossil remains of vertebrata from the Sewalik Hills, the Nerbudda, Perim Island, etc. in the Museum of the Asiatic Society of Bengal, Baptist Mission Press, Calcutta, 268 pp.

FLYNN, L. J., PILBEAM, D., BARRY, J. C., MORGAN, M. E. and RAZA, S. M. 2016. Siwalik synopsis: A long stratigraphic sequence for the Later Cenozoic of South Asia. Comptes Rendus Palevol, 15, 877-887.

GMELIN, J. F. 1789. Caroli a Linné systema naturae per regna tri naturae, secundum classes, ordines, genera, species, cum characteribus, differentiis, synonymis, locis. G. E. Beer, Leipzig.

HEAD, J. J. 2001. Systematics and body size of the gigantic, enigmatic crocodyloid Rhamphosuchus crassidens, and the faunal history of Siwalik Group (Miocene) crocodylians. Journal of Vertebrate Paleontology, 21, A59.

LULL, R. S. 1944. Fossil gavials from North India. American Journal of Science, 242, 417-430. 
LYDEKKER, R. 1886. Siwalik Crocodilia, Lacertilia and Ophidia. Palaeontologia Indica, 3, 209-240.

MARTIN, J. E., BUFFETAUT, E., NAKSRI, W., LAUPRASERT, K., and

CLAUDE, J. 2012. Gavialis from the Pleistocene of Thailand and its relevance for drainage connections from India to Java. PLoS ONE, 7, e44541.

MARTIN, B. G. H. and BELLAIRS, A. D’ A. 1971. The narial excrescence and pterygoid bulla of the gharial, Gavialis gangeticus (Crocodilia). Journal of Zoology, 182, 541-558.

MOOK, C. C. 1932. A new species of fossil gavial from the Siwalik beds. American Museum Novitates, 514, 1-5.

MURCHISON, C. 1868. Palaeontological memoirs and notes of the late hugh Falconer, A.M., M.D. Volume I. Fauna Antiqua Sivalensis. Robert Hardwicke, London. 590 pp.

NAIR, S. P. 2005. "Eyes and no eyes": Siwalik fossil collecting and the crafting of Indian Palaeontology (1830-1847). Science in Context, 18, 359-392.

NANDA, A. C. 2002. Upper Siwalik Mammalian faunas of India and associated events. Journal Asian Earth Sciences, 21, 47-58.

NANDA, A. C. 2013. Upper Siwalik mammalian faunas of the Himalayan foothills. Journal of the Palaeontological Society of India, 58, 75-86.

NANDA, A. C., SCHLEICH, H. H., KOTLIA, B. S. 2016. New fossil reptile records from the Siwalik of North India. Open Journal of Geology, 6, 673-691.

NORELL, M. A. and STORRS, G. W. 1989. Catalogue and review of the type fossil crocodilians in the Yale Peabody Museum. Postilla, 203, 1-28. 
OPPEL, M. 1811. Die Ordnung, Familien und Gattungen der Reptilien als Prodrom einer Naturgeschichte derselben. Lindauer, Munich, 87 pp.

PATNAIK, R. and NANDA, A.C. 2010. Chapter 9. Early Pleistocene mammalian faunas of India and evidence of connections with other parts of the world. In FLEAGLE J. G. et al. (eds)., Out of Africa I: The first hominin colonization of Eurasia, Vertebrate palaeobiology and paleoanthropology, Springer Science.

PATNAIK, R. and SCHLEICH, H. H. 1993. Fossil crocodile remains from the Upper Siwaliks of India. Mitteilungen der Bayerischen Staatssammlung für Paläontologie und historische Geologie, 33, 91-117.

PILGRIM, G. E. 1908. The tertiary and post-tertiary freshwater deposits of Baluchistan and Sind with notices of new vertebrates. Records of the Geological Survey of India, 37, 139-166.

PILGRIM, G. E. 1912. The vertebrate fauna of the Gaj series in the Bugti Hills and the Punhab. Memoirs of the Geological Survey of India. Palaeontologia Indica New Series, 4, 1-83.

PIRAS, P. and KOTSAKIS, P. 2005. A new gavialid from Early Miocene of southeastern Pakistan (preliminary report). Rendiconti Società Paleontologia Italiana, $\mathbf{2}$, 201-207.

WELCOMME, J. L., M. BENAMMI, J. Y. CROCHET, L. MARIVAUX, G. METAIS, P. O. ANTOINE, and I. BALOCH. 2001. Himalayan Forelands: palaeontological evidence for Oligocene detrital deposits in the Bugti Hills (Balochistan, Pakistan). Geological Magazine, 138, 397-405.

WHITAKER R, WHITAKER N. 2008. Who's got the biggest? Crocodile Specialist Group Newsletter, 27, 26-30. 


\section{FIGURE CAPTIONS}

FIG. 1. Map of India and neighboring countries with the main localities having produced fossil Gavialis specimens and other longirostrine taxa discussed in this work. 1, Cautley's historical collecting area in the Siwalik Hills around Pinjor from the Sutlej Valley to the Kallowa Pass, which yielded G. gangeticus, G. hysudricus and G. leptodus; 2, Sehwan in Sindh, Pakistan, which has yielded G. pachyrhynchus and G. curvirostris; 3, Kumbi, Bugti Hills, Pakistan, which yielded G. breviceps; 4, Perim Island, Gulf of Cambay, India, which yielded Gavialis sp; 5, Ava, Myanmar, which yielded remains of Gavialis sp.; 6, the Potwar Plateau, Pakistan, which has recently yielded Rhamphosuchus crassidens (Head, 2001) and Dhok Pathan with G. lewisi; 7, the Gaj series, Pakistan where a specimen was described by Piras \& Kotsakis (2005); 8, Khok Sung, Thailand where G. cf. bengawanicus was reported (Martin et al. 2012). Java is not indicated in this map but has yielded G. bengawanicus Dubois 1908 (see Delfino and De Vos 2010). Major relief is indicated by crosses.

FIG. 2. Selected skulls of Gavialis gangeticus from the Siwalik Hills of India. NHMUK R39809 in A, dorsal; B, ventral; C, occipital and D, left lateral views; NHMUK R36727 in E, dorsal; F, ventral; G, occipital and H, right lateral views; NHMUK R36726 in I, dorsal; J, ventral; K, occipital and L, right lateral views; NHMUK R786 in M, dorsal; N, ventral; O, occipital and P, left lateral views; NHMUK R785 in Q, dorsal; R, ventral; S, occipital and T, right lateral views The asterisk indicates horizontally flipped specimen to ease comparison. The arrows underline the sloping skull table as observed in posterior view. Abbreviations: bt, basioccipital tuber; den, dentary; pb, pterygoid bulla; uo, upturned orbit. Scale bars represent $5 \mathrm{~cm}$.

FIG. 3. Gavialis specimens from the Siwalik Hills of India. Rostrum of Gavialis sp. (NHMUK R39811a) in A, dorsal, B, anterior and C, right lateral views; premaxillae of Gavialis sp. (NHMUK R48461) in D, dorsal, E, ventral and F, anterior views; dentaries curated as Gavialis hysudricus (NHMUK R325) but here referred as Gavialis sp. in G, dorsal and H, ventral views; rostrum of Gavialis sp. (NHMUK R39811) in I, dorsal and J, ventral views; right dentary of Gavialis sp. (NHMUK $\mathrm{R} 48461$ ) in K, dorsal view. Scale bars represent $2 \mathrm{~cm}$. 
FIG. 4. The holotype of Gavialis hysudricus (NHMUK R39805) referred here as Gavialis gangeticus in A, dorsal and B, ventral views. Scale bar represents $5 \mathrm{~cm}$. Abbreviations: den, dentary; ec, ectopterygoid; mx, maxilla; or, orbit; pal, palatine; sof, suborbital fenestra; sp, splenial. Scale bar represents $5 \mathrm{~cm}$.

FIG. 5. Gavialis specimens from the Siwalik Hills of India. Skull specimens curated as Gavialis hysudricus but referred here as unnamed gavialoids: NHMUK R325a in A, dorsal, B, ventral, C, occipital and D, left lateral view; NHMUK R39808 in E, dorsal, F, ventral, G, occipital and $\mathrm{H}$, left lateral view. The asterisk indicates horizontally flipped specimen to ease comparison with Fig. 2. The arrows underline the planar skull table of both specimens as observed in posterior view. Scale bars represent $5 \mathrm{~cm}$.

FIG. 6. Specimens of Gavialis leptodus from the Siwalik Hills of India. NHMUK R39807 in A, occlusal, B, ventral and C, anterior views; NHMUK R39806 in D, occlusal, E, ventral, F, left lateral, G, anterior and H, a close-up on the alveolar collars. Scale bar represents $5 \mathrm{~cm}$.

FIG. 7. Cast of Gavialis pachyrhynchus (NHMUK R602) from the Laki Hills of Sindh in Pakistan in A, dorsal and B, ventral views. Numbers indicate premaxillary alveolar count. Scale bar represents $5 \mathrm{~cm}$.

TABLE 1. Current understanding of the taxonomy of the genus Gavialis from the Siwalik Hills of India and Pakistan. 
age

Pleistocene

Pleistocene

Pleistocene

Pliocene

Pliocene

Plio-Pleistocene

Miocene

Oligo-Miocene

Oligo-Miocene
Country

Pinjor beds, India

Pinjor beds, India

Nathot, Pakistan

Dhok Pathan, Pakistan

Tatrot or Pinjor Formation, India

Laki Hills, Sindh, Pakistan

Laki Hills, Sindh, Pakistan

Kumbi, Bugti Hills, Pakistan
Gavialis gangeticus (Gmelin, 1789)

Gavialis bengawanicus Dubois, 1908

Gavialis browni Mook, 1932

Gavialis lewisi Lull, 1944

Gavialis leptodus (Falconer \& Cautley, 1868)

Gavialis pachyrhynchus Lydekker, 1886

Gavialis curvirostris Lydekker, 1886

Gavialis breviceps Pilgrim, 1912 valid

valid

Gavialis gangeticus

revision needed

revision needed

?juvenile Rhamphosuchus crassidens

cf. Rhamphosuchus crassidens

Rhamphosuchus crassidens or new tomistomine

Rhamphosuchus crassidens or new tomistomine

TABLE 1. Current understanding of the taxonomy of the genus Gavialis from the Siwalik Hills of India and Pakistan. 


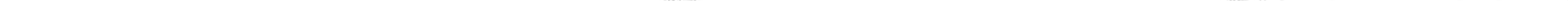



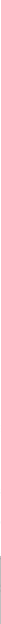

C
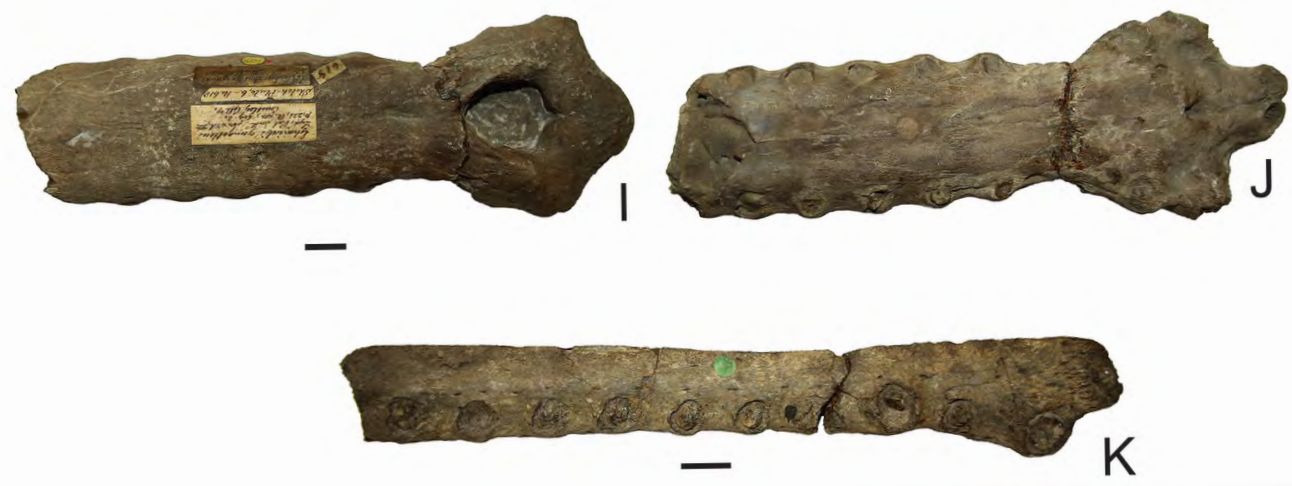


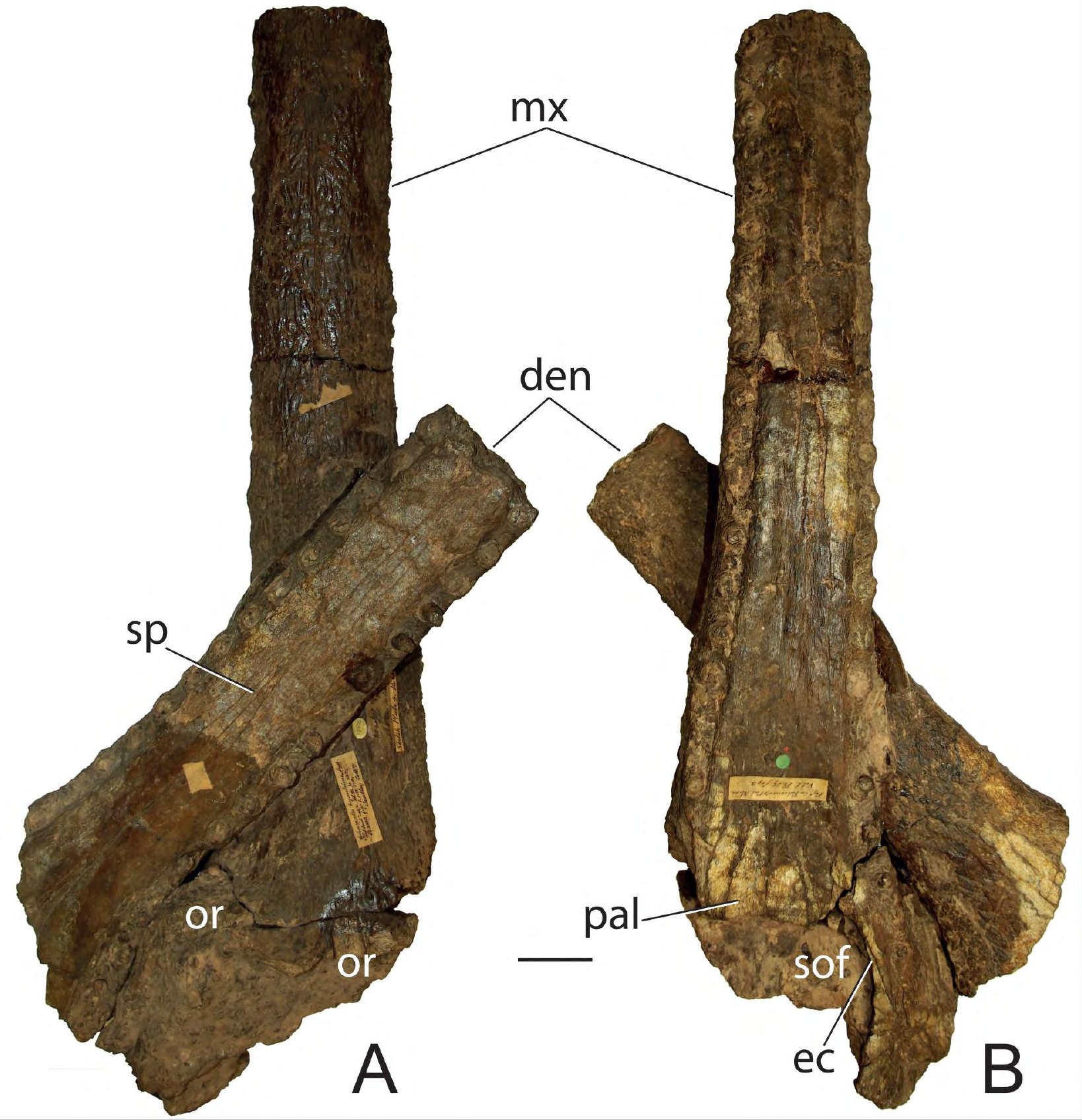




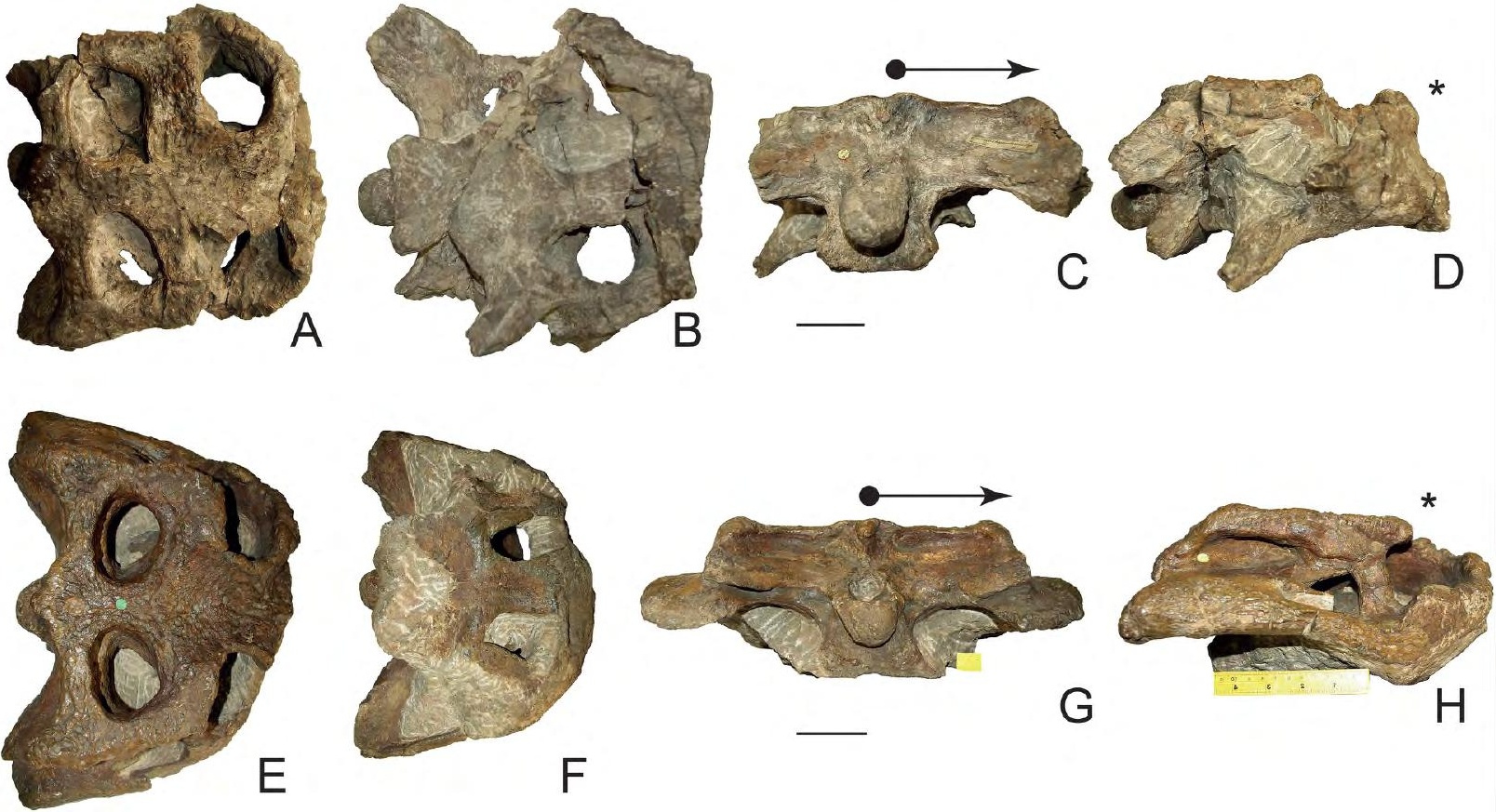



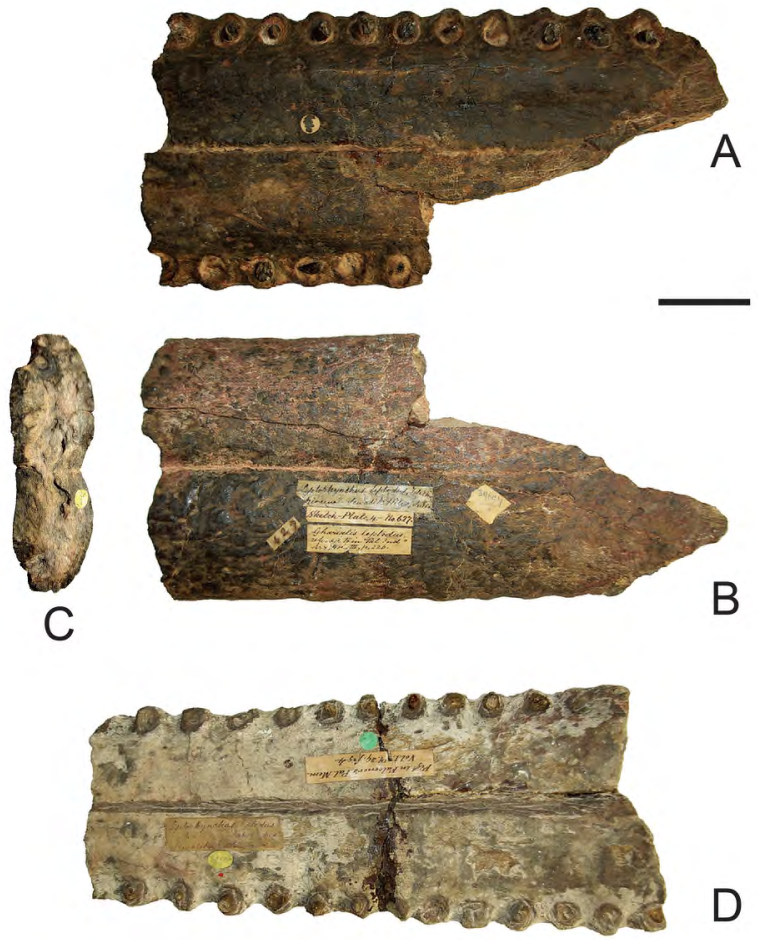

D
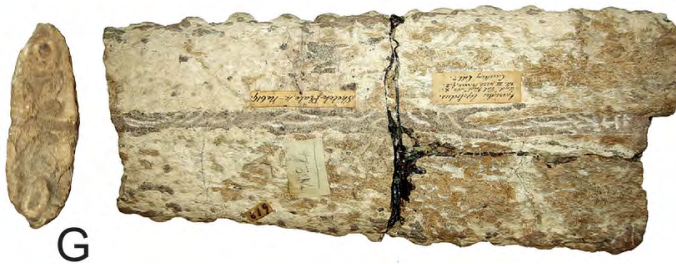

E
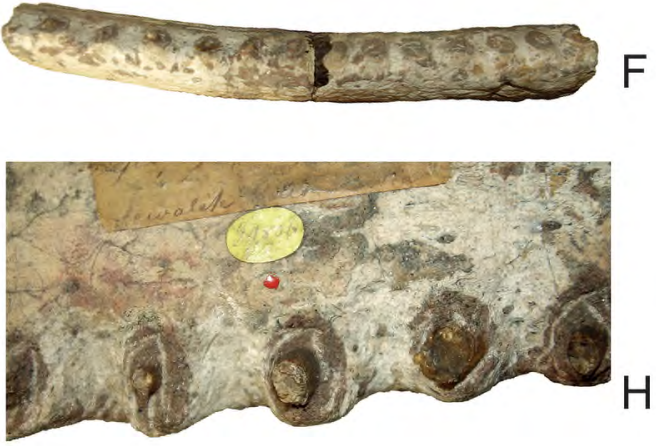

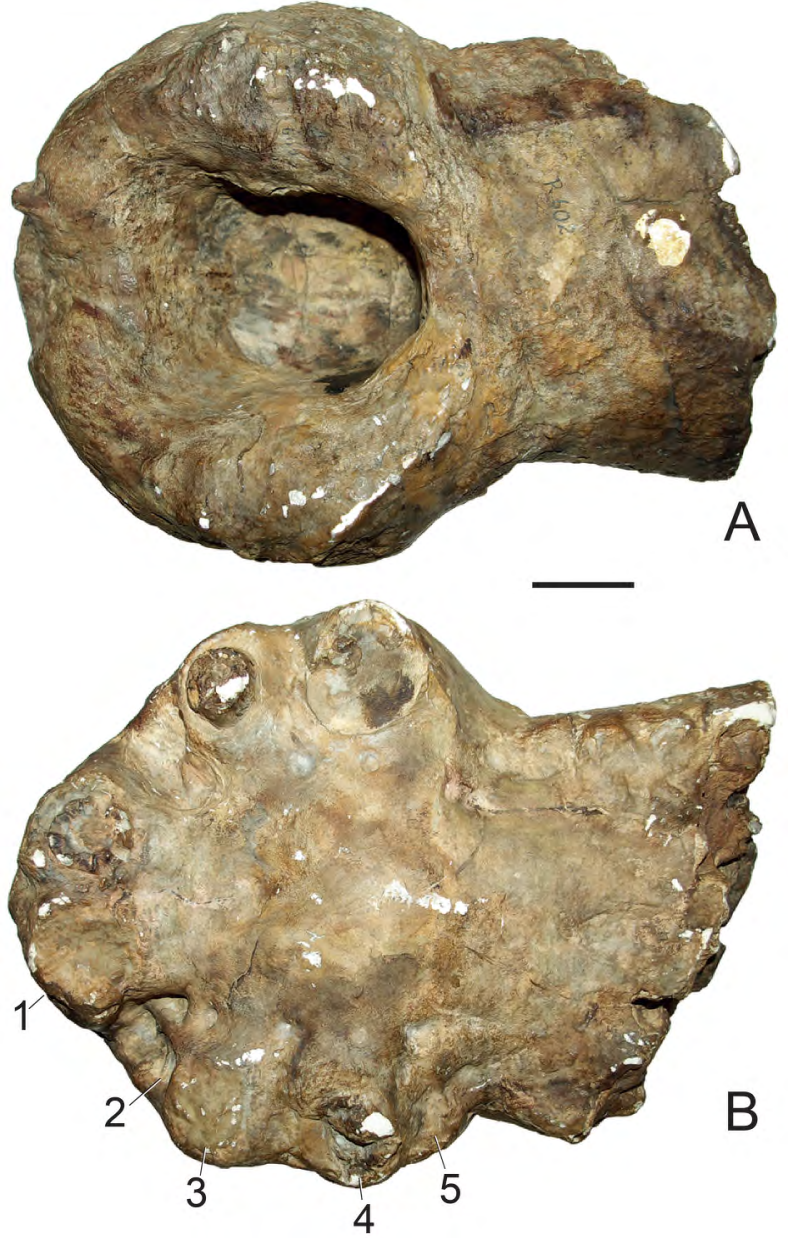